9-15-2006

\title{
(E,E)-1,3-Bis[9,10-dihydro-9-nitro-10-(trinitromethyl)-9-anthr- yl]propane
}

Mustafa Arslan

Sakarya University, Adapazari, Turkey

Erol Asker

Balıkesir University, Balıkesir, Turkey

John Masnovi

Cleveland State University, j.masnovi@csuohio.edu

Ronald J. Baker

Follow this and additional works at: https://engagedscholarship.csuohio.edu/scichem_facpub

Part of the Organic Chemistry Commons

How does access to this work benefit you? Let us know!

\section{Recommended Citation}

Asker, E., Masnovi, J., Baker, R. J., \& Arslan, M. (2006). (E,E)-1,3-bis[9,10-dihydro-9-nitro-10-(trinitromethyl)-9-anthryl]propane. Acta Crystallographica Section E, 62(9), o3650-03651. doi:10.1107/ S1600536806028698

This Article is brought to you for free and open access by the Chemistry Department at EngagedScholarship@CSU. It has been accepted for inclusion in Chemistry Faculty Publications by an authorized administrator of EngagedScholarship@CSU. For more information, please contact library.es@csuohio.edu. 
Acta Crystallographica Section E

\section{Structure Reports}

Online

ISSN 1600-5368

\section{Mustafa Arslan, ${ }^{\text {a* Erol Asker, }}$ John Masnovic and Ronald J. Baker ${ }^{c}$}

a Department of Chemistry, Faculty of Arts and Sciences, Sakarya University, 54140 Esentepe/ Adapazari, Turkey, ${ }^{\mathbf{b}}$ Necatibey Faculty of Education, Balikesir University, 10100 Balikesir, Turkey, and ' ${ }^{\mathbf{C}}$ Department of Chemistry, Cleveland State University, $\mathrm{OH} 44115$, USA

Correspondence e-mail: marslan@sakarya.edu.tr

\section{Key indicators}

Single-crystal X-ray study

$T=295 \mathrm{~K}$

Mean $\sigma(\mathrm{C}-\mathrm{C})=0.006 \AA$

$R$ factor $=0.061$

$w R$ factor $=0.140$

Data-to-parameter ratio $=11.8$

For details of how these key indicators were automatically derived from the article, see http://journals.iucr.org/e.
(C) 2006 International Union of Crystallography All rights reserved

\section{$(E, E)-1,3-B i s[9,10-d i h y d r o-9-n i t r o-10-(t r i n i t r o-$ methyl)-9-anthryl]propane}

The title compound, $\mathrm{C}_{33} \mathrm{H}_{24} \mathrm{~N}_{8} \mathrm{O}_{16}$, was obtained as a product of the photoreaction between 1,3-di-9-anthrylpropane and tetranitromethane. The molecule occupies a special position on a twofold axis. The trinitromethyl and nitro substituents on the 9,10-dihydroacridine system are $E$ oriented.

\section{Comment}

Aromatic amine compounds are of interest due to their potential uses as photoconductive materials in a wide range of electrophotographic devices (Hara \& Omae, 1978; Thelakkat, 2002). One common method for the preparation of aromatic amines is the reduction of the corresponding nitro compounds which are commonly prepared through the reaction of aromatic compounds with concentrated nitric acid in the presence of concentrated sulfuric acid. Nitration through the irradiation of the charge-transfer complexes formed between aromatic compounds and tetranitromethane (TNM) offers an alternative route to the use of concentrated acids (Kochi, 1991; Butts et al., 1996; Cox, 1998; Lehnig \& Schürmann, 1998). We have already reported the crystal structure of $(E)-9,10$ dihydro-9-methyl-9-nitro-10-(trinitromethyl)anthracene as the product of the photoreaction between 9-methylanthracene and TNM (Arslan et al., 2005). In the present paper, we report the crystal structure of the title compound, (I), which is a product of the photoreaction between 1,3-di-9-anthrylpropane, a dimeric analogue to 9-methylanthracene, with TNM.

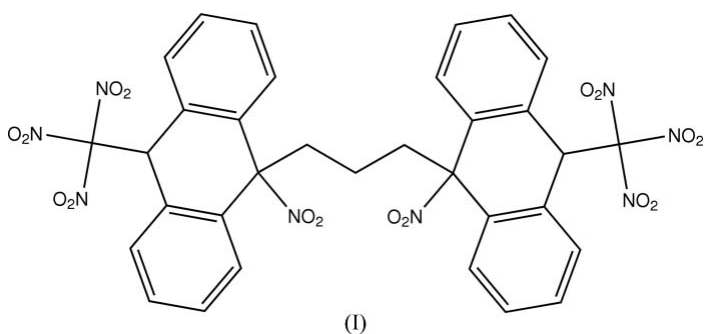

The asymmetric unit contains one half-molecule; the other half is generated by a crystallographic twofold axis operation. Bond lengths and angles (Table 1 ) are similar to those of $(E)$ 9,10-dihydro-9-methyl-9-nitro-10-(trinitromethyl)anthracene (Arslan et al., 2005).

The propylene bridge connecting the two rings shows an anti-anti conformation. The central ring of the 9,10-dihydroanthracene unit adopts a boat conformation with a dihedral angle between the two benzene ring planes of $25.86(13)^{\circ}$. The trinitromethyl group is attached pseudoaxially at the $\mathrm{C} 10$ position of the meso ring. The trinitromethyl and nitro groups on the meso ring are $E$ oriented.
Received 11 July 2006 Accepted 24 July 2006 
The crystal packing is mainly determined by van der Waals forces and, contrary to the structure of the monomeric analogue (Arslan et al., 2005), no intermolecular $\pi-\pi$ stacking interactions are observed.

\section{Experimental}

The title compound was synthesized by irradiation for $60 \mathrm{~min}$ of a solution of 1,3-di-9-anthrylpropane $(20 \mathrm{mg}, 0.051 \mathrm{mmol})$ and TNM (325 mg, $1.67 \mathrm{mmol}$ ) in a $40 \mathrm{ml}$ pentane $/ 5 \mathrm{ml} \mathrm{CCl}_{4}$ mixture, according suitable for X-ray diffraction studies were grown from a concentrated solution of (I) in chloroform through slow evaporation of solvent at ambient conditions [22.36\% yield $(9.0 \mathrm{mg}, 0.0114 \mathrm{mmol})$, m.p. $439-$ $440 \mathrm{~K}]$.

\section{Crystal data}

$$
\begin{aligned}
& \mathrm{C}_{33} \mathrm{H}_{24} \mathrm{~N}_{8} \mathrm{O}_{16} \\
& M_{r}=788.6 \\
& \text { Monoclinic, } C 2 / c \\
& a=23.388(3) \AA \\
& b=9.4054(10) \AA \\
& c=16.3442(11) \AA \\
& \beta=107.161(7)^{\circ} \\
& V=3435.2(6) \AA^{3}
\end{aligned}
$$

\section{Data collection}

Enraf-Nonius CAD-4

diffractometer

$\omega$ scans

Absorption correction: none

3049 measured reflections

3049 independent reflections

\section{Refinement}

Refinement on $F^{2}$

$R\left[F^{2}>2 \sigma\left(F^{2}\right)\right]=0.061$

$w R\left(F^{2}\right)=0.140$

$S=1.11$

3049 reflections

258 parameters

$\mathrm{H}$-atom parameters constrained

$$
\begin{gathered}
w=1 /\left[\sigma^{2}\left(F_{\mathrm{o}}{ }^{2}\right)+(0.0444 P)^{2}\right. \\
+3.4205 P] \\
\text { where } P=\left(F_{\mathrm{o}}^{2}+2 F_{\mathrm{c}}{ }^{2}\right) / 3 \\
(\Delta / \sigma)_{\max }<0.001 \\
\Delta \rho_{\max }=0.21 \AA^{-3} \\
\Delta \rho_{\min }=-0.23 \mathrm{e}^{-3}
\end{gathered}
$$
to the procedure reported earlier (Arslan et al., 2005). Single crystals

$$
\begin{aligned}
& Z=4 \\
& D_{x}=1.525 \mathrm{Mg} \mathrm{m}^{-3} \\
& \text { Mo } K \alpha \text { radiation } \\
& \mu=0.13 \mathrm{~mm}^{-1} \\
& T=295(2) \mathrm{K} \\
& \text { Thick plate, colorless } \\
& 0.2 \times 0.2 \times 0.1 \mathrm{~mm}
\end{aligned}
$$

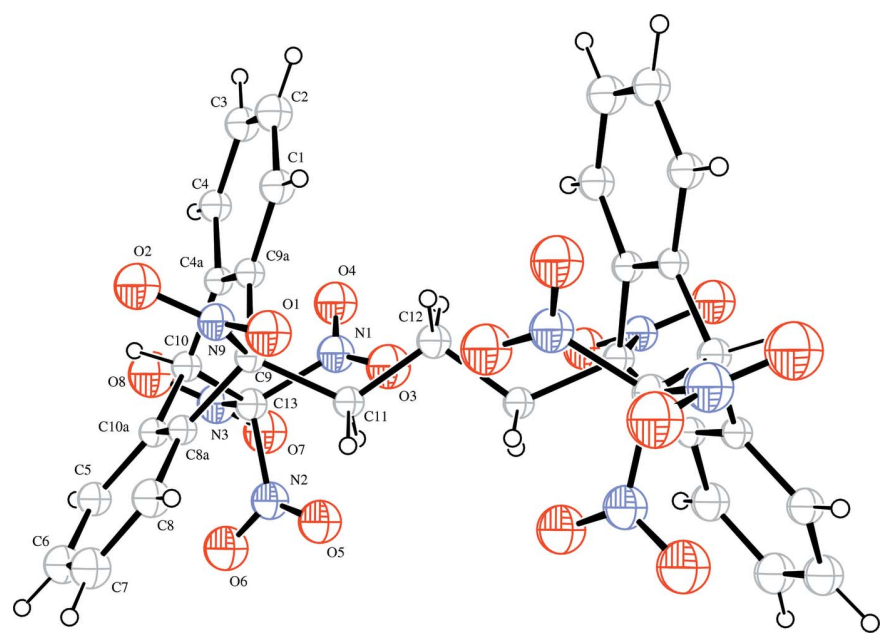

Figure 1

Molecular structure of (I) with the atom-numbering scheme. Displacement ellipsoids for non-H atoms are drawn at the $30 \%$ probability level. Unlabeled atoms are related to labeled atoms by the symmetry operator $\left(1-x, y, \frac{1}{2}-z\right)$.

aromatic, methylene, and methine $\mathrm{H}$ atoms, respectively, and with $U_{\text {iso }}(\mathrm{H})=1.2 U_{\text {eq }}(\mathrm{C})$.

Data collection: CAD-4-PC Software (Enraf-Nonius, 1993); cell refinement: $C A D-4-P C$ Software; data reduction: DATRD2 in NRCVAX (Gabe et al., 1989); program(s) used to solve structure: SHELXS97 (Sheldrick, 1997); program(s) used to refine structure: SHELXL97 (Sheldrick, 1997); molecular graphics: ORTEP-3 for Windows (Farrugia, 1997) and PLATON (Spek, 2003); software used to prepare material for publication: WinGX (Farrugia, 1999).

The authors thank the Turkish Ministry of Education and the CSU College of Graduate Studies for their support of this work.

\section{References}

Arslan, M., Baker, R. J., Masnovi, J. \& Asker, E. (2005). Acta Cryst. E61, 04133-04135.

Butts, C. P., Eberson, L., Hartshorn, M. P., Robinson, W. T., TimmermanVaughan, D. J. \& Young, D. A. W. (1996). Acta Chem. Scand. 50, 29-47.

Cox, A. (1998). Photochemistry, 29, 164-203.

Enraf-Nonius (1993). CAD-4-PC Software. Version 1.2. Enraf-Nonius, Delft, The Netherlands.

Selected geometric parameters $\left(\AA,^{\circ}\right)$.

\begin{tabular}{llll}
\hline $\mathrm{N} 1-\mathrm{C} 13$ & $1.529(5)$ & $\mathrm{N} 9-\mathrm{C} 9$ & $1.561(4)$ \\
$\mathrm{N} 2-\mathrm{C} 13$ & $1.534(5)$ & $\mathrm{C} 9-\mathrm{C} 11$ & $1.542(5)$ \\
$\mathrm{N} 3-\mathrm{C} 13$ & $1.538(5)$ & $\mathrm{C} 10-\mathrm{C} 13$ & $1.570(5)$ \\
& & & \\
$\mathrm{C} 8 A-\mathrm{C} 9-\mathrm{C} 9 A$ & $113.8(3)$ & $\mathrm{C} 9 A-\mathrm{C} 9-\mathrm{C} 11$ & $114.5(3)$ \\
$\mathrm{C} 8 A-\mathrm{C} 9-\mathrm{C} 11$ & $108.8(3)$ & $\mathrm{C} 4 A-\mathrm{C} 10-\mathrm{C} 10 A$ & $113.3(3)$ \\
\hline
\end{tabular}

All $\mathrm{H}$ atoms were placed geometrically and allowed to ride on their parent atoms with $\mathrm{C}-\mathrm{H}$ distances of $0.93,0.97$ and $0.98 \AA$ for
Farrugia, L. J. (1997). J. Appl. Cryst. 30, 565.

Farrugia, L. J. (1999). J. Appl. Cryst. 32, 837-838.

Gabe, E. J., Le Page, Y., Charland, J.-P., Lee, F. L. \& White, P. S. (1989). J. Appl. Cryst. 22, 384-387.

Hara, S. \& Omae, I. (1978). US Patent 4218247.

Kochi, J. K. (1991). Pure Appl. Chem. 63, 255-264.

Lehnig, M. \& Schürmann, K. (1998). Eur. J. Org. Chem. pp. 913-918.

Sheldrick, G. M. (1997). SHELXS97 and SHELXL97. University of Göttingen, Germany.

Spek, A. L. (2003). J. Appl. Cryst. 36, 7-13.

Thelakkat, M. (2002). Macromol. Mater. Eng. 287, 442-461. 